\title{
Group composition and activity patterns of brown-nosed coatis in savanna fragments, Mato Grosso do Sul, Brazil
}

\author{
Costa, EMJ. ${ }^{\mathrm{a} *}$, Mauro, RA. ${ }^{\mathrm{b} *}$ and Silva, JSV. ${ }^{\mathrm{c} *}$ \\ ${ }^{a}$ Laboratório de Ecologia, Departamento de Biologia, Universidade Federal de Mato Grosso do Sul - UFMS, \\ Campo Cidade Universitária, s/n, CEP 79070-900, Grande, MS, Brazil

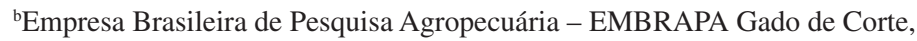 \\ Campo Grande, MS, Brazil \\ ${ }^{\circ}$ Empresa Brasileira de Pesquisa Agropecuária - EMBRAPA Informática Agropecuária, \\ Av. André Tosello, 209, Barão Geraldo, CP 6041, CEP 13083-970, Campinas, SP, Brazil \\ *e-mail: emjcosta@gmail.com, rodiney@cnpgc.embrapa.br, jvilla@cnptia.embrapa.br \\ Received August 27, 2007 - Accepted March 24, 2008 - Distributed November 30, 2009
}

(With 3 figures)

\begin{abstract}
The Parque Estadual do Prosa (PEP), in Campo Grande, MS, is an urban fragment of savanna (cerrado) and tall savanna woodland (cerradão), with an area of $1,335 \mathrm{~km}^{2}$, where the population density of brown-nosed coatis is 33.71 individuals $/ \mathrm{km}^{2}$. Our results suggest that seasonality at the PEP causes changes in the availability of resources for coatis, altering their home range areas, their dispersion patterns and their daily behaviour. And our observations regarding male-band associations, agonistic interactions between bands and their daily behaviour emphasize the plasticity of coati social structure, and its potential for future comparative studies.
\end{abstract}

Keywords: Nasua nasua, savannah fragment, seasonality.

\section{Composição de grupo e padrões de atividades de quatis em fragmento de cerrado}

\begin{abstract}
Resumo
O Parque Estadual do Prosa, em Campo Grande, MS, é um fragmento urbano de cerrado e cerradão, com uma área de $1.335 \mathrm{~km}^{2}$, onde a densidade populacional dos quatis é de 33,71 indivíduos $/ \mathrm{km}^{2}$. Nossos resultados sugerem que a sazonalidade no PEP provoca mudanças na disponibilidade de recursos para os quatis, alterando sua área de vida, seus padrões de movimentação e seu comportamento diário. E nossas observações, quanto às associações macho-bando e interações agonísticas entre bandos e comportamento, enfatizam a plasticidade da estrutura social do quati e seu potencial para futuros estudos comparativos.
\end{abstract}

Palavras-chave: Nasua nasua, fragmento de cerrado, sazonalidade.

\section{Introduction}

There are three species of Nasua, a highly social carnivore of the Procyonidae family exclusive to America, the white-nosed coati, $N$. narica can be found from the South of Arizona and Southwest of New Mexico, down south through Mexico to and Central America up to northern Colombia in the Golf of Uruba. The brownnosed coati, N. Nasua, is distributed in South America from northern Colombia to northern Argentina. Its distribution is allopathic, in a region between Panama and Colombia. And the dwarf or Cozumel's coati, N. nelsoni, is endemic to Cozumel Island, Mexico (Decker, 1991; Gomper, 1995; Gomper and Decker 1998; Cuarón, 2004; McFadden, 2004).

They are gregarious, diurnal, and present a synchronous breeding season. The adult females and juveniles

form social groups made up of 5 to 70 individuals called bands, which display a variety of cooperative behaviours (coalition formation, grooming, baby-sitting, anti-predator behaviour). Coatis are highly philopatric, and the majority of the adult members are relatively close genetically, although unrelated individuals can occasionally come into the group (McClearn, 1992; Gompper, 1997; Gompper and Decker, 1998). On the other hand, the adult males remain solitary with the exception of a short period during the breeding season. They also present dispersal behaviour (Gompper, 1997; Alves-Costa, 1998; McFadden, 2004). However, their dispersal distance is usually small, with their home range including or being close to their birth area. 
Coatis occupy essentially forested habitats, feeding mainly on fruits (Gompper, 1997; Beisiegel, 2001; AlvesCosta et al., 2004). Thus, the seasonal availability of fruit strongly influences population structure and reproduction. Several studies (e. g. Russel, 1982; Gompper and Krinsley, 1992; Yanoski and Mercolli, 1992; Gompper, 1996; 1997; Gompper and Decker, 1998; Valenzuela and Ceballos, 2000; Beisiegel, 2001; Valenzuela and Macdonald, 2002; Alves-Costa et al., 2004; Beisiegel and Mantovani, 2006) have reported significant changes in diet, home range, dispersal patterns and breeding season associated with the wet and dry seasons.

The lack of population studies of $N$. nasua in the wild has led to a severe underestimation of the ecological problems and decline in numbers affecting this species in South America. Unregulated hunting, pet trading and habitat destruction are the main problems that threaten N. nasua populations in Paraguay, Bolivia, Argentina, Venezuela and Uruguay. In the latter country, $N$. nasua is protected under CITES Appendix III (Emmons 1990). Despite its broad geographical distribution and relative abundance in Brazil, according to Cheida et al. 2006, this species is classified as vulnerable in southern Brazil (Rio Grande do Sul). Deforestation and the consequent destruction and fragmentation of its habitat associated with hunting and road-killing are the main factors responsible for this status.

We studied group composition and activity patterns of brown-nosed coatis and the influence of climatic seasonality on these features in an urban savanna fragment. Based on the climatic conditions of our study site, and on what has been reported previously for Nasua, we made several predictions. First, we expected to find seasonal differences in dispersal patterns, with larger daily distances travelled in the dry season compared with the wet season. Second, we predicted that home-range size would vary seasonally, with larger sizes during the dry compared to the wet season. And third, the behaviour patterns of coatis would vary seasonally, with lower intensity of activity in dry season.

\section{Material and Methods}

\subsection{Study area}

The Parque Estadual do Prosa (PEP) is a 134-hectare reserve located on the Maracaju Highland (600 $\mathrm{m}$ above sea level). It is a fragment of savanna (cerrado) and tall savanna woodland (cerradão) isolated from urban buildings and roads in the urban perimeter of Campo Grande, state of Mato Grosso do Sul, Brazil. We use the concept of the cerrado presented by Barbosa (1996), with six main categories: field clean (campo limpo), cerrado strictu sensu, cerradão, forest, riparian forest, veredas and inundating environments. Basically, three types of vegetation cover are found at the PEP: cerrado sensu stricto, cerradão (a tall woodland) and riparian forest.
The total annual precipitation ranges between $1,300 \mathrm{~mm}$ and 1,700 mm (SEMA 2000).

\subsection{Data collection}

From August to October, 2001, we followed constantly several coati bands at our study sites, and three were habituated to our presence and provided most of our observations. The individuals were identified by using natural marks, scars from botflies and fights, and other anatomic details. Coatis were classified according to their body size and weight in the following classes: young (small body size, up to $500 \mathrm{~g}$ ), juvenile (up to 12 months, $500 \mathrm{~g}-2 \mathrm{~kg}$ ), sub-adult (12-24 months, 2-3 kg) and adult (>24 months, above $3 \mathrm{~kg}$, Gompper 1997).

From November 2001 to August 2002, when one of the bands was located, we systematically collected, twice a week during daylight (6:00 AM to 6:00 PM), data on group, composition and size, population density, home range, activity patterns, behaviour and recruitment of groups of coatis observed at the study site.

\subsection{Behaviour}

To facilitate the location of the habituated bands, we went to the places most frequented by coatis. To find them, we provided small pieces of food to prevent an escape response with alarm vocalisation or rapid running. Ten minutes after all of the members of a band had become aware of our presence and we had ceased feeding them, we began collecting the data. Scan sample of the main behaviour patterns such as foraging, resting, grooming and travelling were collected every 30 minutes in recording sessions of 60 seconds. Data on agonistic interactions (e.g. active hostile behavior and/or actual fights) were collected ad libitum (Altmann 1974). Additional data, such as registration of new individuals still unknown and their displacement were also recorded while following the bands.

\subsection{Population density, home range and daily distance travelled}

The population density was determined by the repeat transect method (Buckland et al. 1993). The PEP was divided in 4 transects of 470, 520, 575 and $655 \mathrm{~m}$ in length respectively, throughout the different types of vegetation cover, the transects were marked every $20 \mathrm{~m}$. Transects were sampled systematically, twice a month, in the morning (between $\mathrm{X} \mathrm{hr}$ and Xhr) and in the afternoon (between $\mathrm{X} \mathrm{hr}$ and Xhr). Observers walked slowly (0.6-1.5 km/h, Emmons, 1984) along the centre of each transect, recording the date, trail id, starting and termination time of the census and each time a coati was observed the following data: approximate location on the trail, time of sighting, the distance from the observer to the first animal seen, the perpendicular distance of the closest animal to the trail, and the group size and composition.

Other information such as direction of travel, habitat type, and activity at time of sighting was also recorded. The location of the bands and the direction of travel 
were marked on a map showing the transect paths. The number of coati bands in and near the area was estimated by counting areas showing a concentration of sightings. Repeated counts of the same group or individual were avoided on the basis of unusual coloration, scars or other individual peculiarities. The formula for estimating density was: $\mathrm{D}=\mathrm{N} /(2 * \mathrm{ESW} * \mathrm{~L})$ where $\mathrm{D}=$ density (individuals $/ \mathrm{km}^{2}$ ); $\mathrm{N}=$ total number of encounters; $\mathrm{ESW}=$ total width of the area sampled in $\mathrm{km}^{2}$, calculated by the program DISTANCE 4.1; L = total kilometres covered (Burnham et al., 1980; Cullen Jr. and Rudran, 2003). The size of the population was calculated by multiplying the density by the total area of the PEP.

The minimum daily path was calculated using the sum of distances between all points of location taken for each band every 30 minutes. Seasonal home range areas for each band were estimated as the $95 \%$ Harmonic Mean contour (Dixon and Chapman, 1980) using 95\% points collected for each band on each season. The harmonic mean centre is a close approximation of the true activity centre, the bias depending only on the grid density. These features of the harmonic mean measure make it possible to compare an animal's activity with its habitat whether homogeneous or heterogeneous (Dixon and Chapman, 1980).

\section{Results}

Three bands of coatis and five adult males were found and followed during the study. The bands were named A, $\mathrm{B}$ and $\mathrm{C}$, and the males M1, M2, M3, M4 and M5. Band A is composed of twenty animals, four adult females and sixteen youngs, born either in September or October of 2001. All survived, and in 2002 they became juveniles, as young at around one year old are called (Russel 1982, Gompper 1997). Band B is composed of five adult females and eight young, born in the same period as the ones in group A. They became juvenile in 2002. Group C is smaller, composed of seven females with no young or subadult. The sex ratio among adults in the PEP was of three females for one male. The total number of observations obtained for each band is presented in Table 1 .

\subsection{Behaviour}

Of the total 142 observations in an interval of $30 \mathrm{~min}-$ utes of band A over the study period, 130 are accompanied by the Adult Male (AM) 1, eight are accompanied

Table 1. Total number of observations, every 30 minutes focal sampling, of the bands of coatis A, B and C, in the Parque Estadual do Prosa, Campo Grande, Mato Grosso do Sul, in the rainy and dry season.

\begin{tabular}{cccc}
\hline Bands & \multicolumn{2}{c}{ Number of observations } & \multirow{2}{*}{$\begin{array}{c}\text { Total of } \\
\text { observations }\end{array}$} \\
\cline { 2 - 3 } & Rainfall & Dry & 142 \\
A & 39 & 103 & 31 \\
B & 23 & 8 & 14 \\
C & 9 & 5 & \\
\hline
\end{tabular}

by the AM 4, five by AM 5 and nine are without macho; of the total 32 observations of band $\mathrm{B}$, twenty-three are accompanied by AM 2, two by AM 3, one by AM 4 and six are without macho; and of the total 14 observations of band C, eight are accompanied by AM 2, one by AM 3, and five are without any male (Figure 1).

Among the five adult males, two of them, AM1 and AM2, accompanied almost all the time bands A and B respectively, interacting with their members without aggressive behaviour. The other males (AM3, AM4 and AM5) have been observed only during the mating period, when they approach the bands. In the PEP we recorded that the mating period occurs from July to August.

The frequency of agonistic encounters between males is larger during the reproductive season, which coincides with the dry months (Figure 2). The frequency of agonistic encounters between bands during foraging is larger during the dry season (Figure 2), the time in which band A, when present, always maintained the food resources.

Coati daily activity and behaviour pattern in the PEP seems to also be influenced by seasonality. Coati daily resting period tends to be concentrated around midday during the dry season, while in the wet season the resting periods present a more uniform distribution over the day (Figure 3).

\subsection{Population density, daily distance travelled and home range}

Currently, a total of 45 coatis has been observed living in an area of $1.34 \mathrm{~km}^{2}$ (134 hectares), resulting in population density of about 33.71 individuals $/ \mathrm{km}^{2}$.

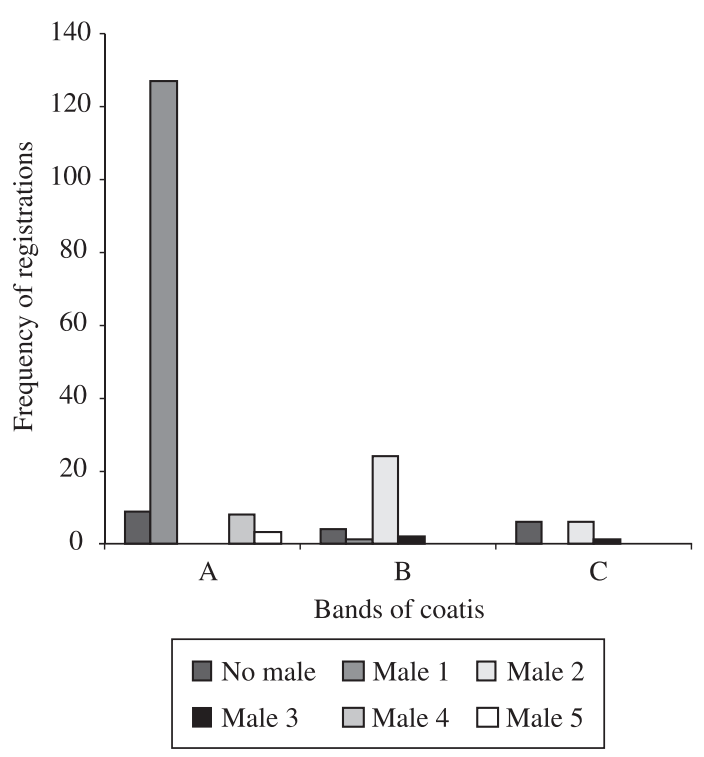

Figure 1. Frequency of registration of the bands (A, B and C) accompanied or not by male in the Parque Estadual do Prosa, Campo Grande, Mato Grosso do Sul. 

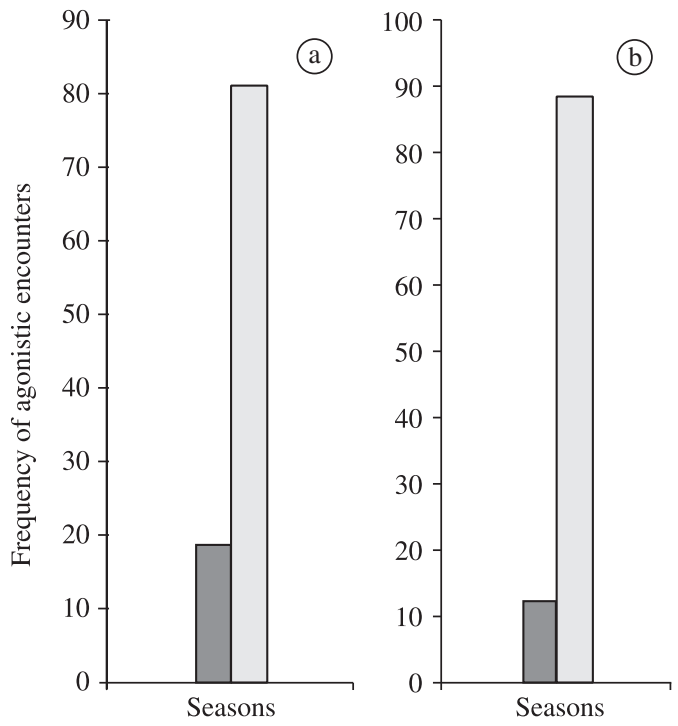

Rainfall $\square$ Dry

Figure 2. Frequency of agonistic encounters among bands (a) during the foraging and encounters among adult males (b) in the rainy and the dry season in the Parque Estadual do Prosa, Campo Grande, Mato Grosso do Sul.

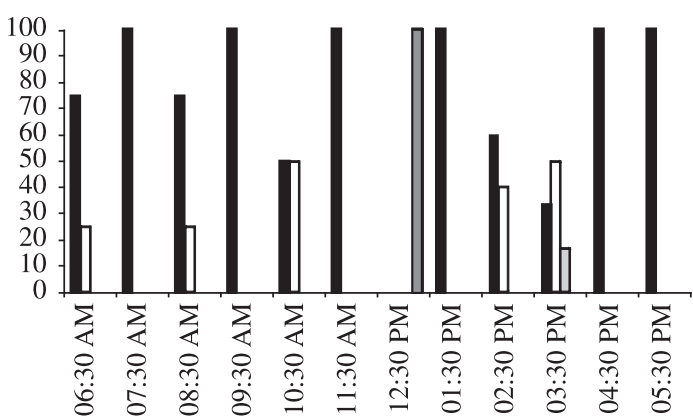

Classes of time intervals

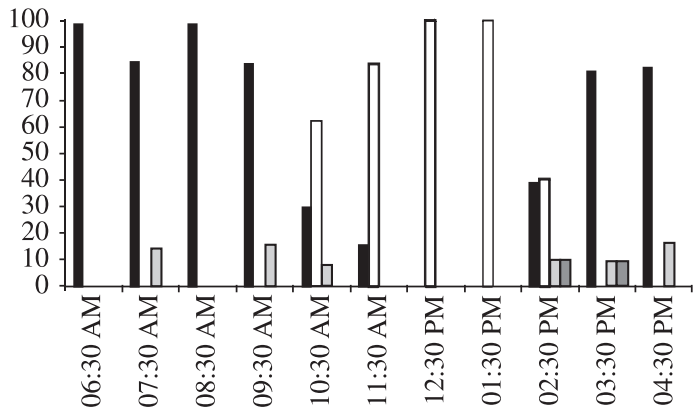

Classes of time intervals

Foraging $\square$ Resting $\square$ Traveling $\square$ Grooming

Figure 3. Frequency of behaviour of band A in the rainy and the dry season in the Parque Estadual do Prosa, Campo Grande, Mato Grosso do Sul. The classes of time intervals are of 1 hour, denominated on the graph by inferior limit.
$88.8 \mathrm{~km}$ were covered with effort sample of 192 transects in twelve months, and 96 encounters with coatis were recorded. $(\mathrm{ESW}=2,8(1,6-4,8)$ effective strip width in metres; $\mathrm{L}=88.8 \mathrm{~km} ; \mathrm{N}=45$ (38-52) (total population, estimated at 4.1 DISTANCE); $\mathrm{CI}=95 \%$ ).

Home range sizes and average daily distance travelled by each band, in each season are presented in Table 2. Band A presented a smaller home range size during the rainy season, with an average distance between points of $72.10 \mathrm{~m}(\mathrm{n}=39)$. During the dry season, band $\mathrm{A}$ increased its home range size, while decreasing the travelling distance, presenting an average distance between points of $49.53 \mathrm{~m}(\mathrm{n}=103)$ (Table 2).

Band $\mathrm{B}$ also presented seasonal changes in its home range, with a smaller area in the rainy season $\left(0.14 \mathrm{~km}^{2}\right)$ $(\mathrm{n}=23)$ and a bigger area in the dry season $\left(0.212 \mathrm{~km}^{2}\right)$ $(n=8)$. However, contrary to band A, they travelled more in the dry (average distance between points of $214.87 \mathrm{~m}$ ) than in the wet months (minimum daily path of $42.95 \mathrm{~m}$ ) (Table 2). For Band $\mathrm{C}$, home range area and daily distance travelled has been computed only for the rainy season, since during the dry season we collected few observations for this band. Its home range area has been found to be $0.15 \mathrm{~km}^{2}(\mathrm{n}=9)$, with average distance between points of $46.88 \mathrm{~m}$ (Table 2).

\section{Discussion}

It has been shown that resource availability is related with coati density. Our density estimate for the PEP (33.71 coatis $/ \mathrm{km}^{2}$ ) is comparatively lower than values from other places with higher resource abundance or lower resource limitation, such as Barro Colorado (51.5 coatis $\left./ \mathrm{km}^{2}\right)$ (Gompper, 1997) or Cuixmala (55.6 coatis $\left./ \mathrm{km}^{2}\right)$, a region in the Chamela Cuixmala Biosphere Reserve, Mexico (Valenzuela and Macdonald, 2002).

The higher density at Barro Colorado has been explained by the absence of hunting pressure and by the availability of food resources in surrounding areas of this island, since its geography allows the coatis to leave the island (Russel, 1982; Russel, 1983; Gompper, 1997). Higher availability of water and reduced impact of the drought in the food resources, has been pointed out as responsible for the higher population density in Cuixmala relative to Cumbres (26.9 coatis $\left./ \mathrm{km}^{2}\right)$, a different area in the same reserve.

The main factor affecting the population growth on the PEP might be the isolation of this fragment of savanna, which limits the availability of resources and dispersion altering reproductive and survival probabilities. Alternatively, as judging from reports of the Center for Rehabilitation of Wild Animals (CRAS), belonging to the PEP, road kills on highways around the reserve might also have a relevant impact on coati density at the PEP.

The sex ratio found at the PEP differs from the one found at Barro Colorado Island of 1:1 (Gompper, 1997). Sex ratio fluctuations may occur year-to-year (Russel, 
Table 2. Calculation of the home range and average distance between points travelled/seasons ( \pm standard error), of the bands of coatis A, B and C, in the Parque Estadual do Prosa, Campo Grande, Mato Grosso do Sul, in the rainy and the dry season. Method: HMN = Harmonic Mean, 95\%. Values on the same line followed by the same letter did not differ significantly (Tukey test, $\alpha=0.05$ )

\begin{tabular}{ccccc}
\hline Bands & Area $\left(\mathbf{k m}^{\mathbf{2}}\right)$ & Dry season & Rainy season & $\begin{array}{c}\text { ANOVA } \\
(\mathbf{n}=\mathbf{1 8 2} ; \mathbf{g l}=\mathbf{4})\end{array}$ \\
\hline A & 0.15 & $49.53( \pm 36.98) \mathrm{a}$ & $72.10( \pm 26.74) \mathrm{b}$ & $\mathrm{F}=36.48$ \\
$\mathrm{~B}$ & 0.14 & $214.87( \pm 96.15) \mathrm{c}$ & $42.95( \pm 34.32) \mathrm{a}$ & $\mathrm{p}<0.000$ \\
$\mathrm{C}$ & 0.15 & $46.88( \pm 24.67) \mathrm{a}$ & - & - \\
\hline
\end{tabular}

1982; Russel, 1983; Gompper, 1997), thus the result obtained at the PEP may be subject to changes, since the data is based only on one year of study. There is a strong female bias in the PEP coati population. However, the number of females effectively breeding depends on ecological conditions, such as food availability and nesting areas (Russel, 1982). Thus, a large number of adult females do not necessarily mean available females for mating.

Several authors recorded significant changes in diet, home range, dispersal pattern, daily behaviour and breeding season between wet and dry seasons in different regions: the Atlantic forest of Brazil (Beisiegel, 2001; Beisiegel and Mantovani, 2006), Minas Gerais savannas (Alves-Costa et al., 2004), dry tropical forest in Mexico (Valenzuela and Ceballos, 2000; Valenzuela and Macdonald, 2002).

At PEP, home range and dispersal pattern of bands $\mathrm{A}, \mathrm{B}$ and $\mathrm{C}$ also presented seasonal changes. This pattern may be due to the small productivity of Brazilian savannas during the drought (Gottesberger and Gottesberger, 1983) and a concentration of flowering and fruiting in the rainy season (Weiser and Godoy, 2001).

Low food availability and high agonistic interactions during the mating period may be responsible for the increase of home range size noted for bands A and B during the dry season. However, bands A and B presented different movement patterns, with band B being more mobile and presenting larger number of encounters with band $\mathrm{A}$ in the periphery of the home range.

The above result may be explained because during the dry season, coatis travel less and tend to occupy patches of resources (e.g. a fruiting tree) where the food resource is abundant. They remain in these patches until the food runs out, since the likelihood of finding better patches is small. Once the resource is over, they seek more distant patches, thus the home area range increases. In spite of that, they travel less than the average daily path length since they will spend more time in every food patch they find. Their movement pattern is adjusted in a way to optimise energy and guarantee the richest food patches. Food scarcity supports the increase in the home range size to search for food.

Agonistic interactions have been displayed mainly in the context of food resource (during foraging), especially in the dry season. This interaction is probably due to the larger group size of band A members. However, interband peaceful interactions have been also observed during the wet season, when bands could be found sharing the same foraging area or tree.

The social behaviour of some of the adult males observed in this study seems to differ from that recorded in the literature, which reports that adult males are solitary (Gompper, 1997). The male habit of travelling alone, led N. nasua to be referred to as coati mundi, or solitary coati in the Brazilian vernacular (Gompper, 1995; Gompper and Decker, 1998), the common name "coati" is the Tupian Indian origin (cua = belt, tim = nose), referring to the coati's sleeping position with the nose tucked on the belly (Lias, 1987; Kauffmann, 1962 apud Gompper and Decker, 1998). It is common knowledge that solitary adult males overlap their home range with the ranges of other males, including or being close to the home range of its original band (e. g. Russel, 1982; 1983; Ratnayeke et al., 1994; Gompper, 1995; 1997; Gompper and Decker, 1998; Valenzuela and Ceballos, 2000). However, PEP adult males have been observed, out of the breeding season, most of the time associated with a particular band. The companion male was usually the same animal for the band. Male M1 followed band A and the male M2 followed band B. Similar behaviour has been observed to occur on Barro Colorado Island, in Arizona, New Mexico and in Mexico (Gompper, 1995; 1997), although on this island the adult male association with the bands was reported to be sporadic. In Panama Gompper and Krinsley (1992) registered several adult male accompanying bands outside the breeding season, when male displayed social behaviour similar to other band members was observed, in grooming interactions with sub-adults and adult females. As in Panama, in PEP bands mate synchronously, so this phenomenon cannot be explained strictly as a monopolisation of mating opportunities. In Argentina, ring-tailed coatis exhibit an extreme form of juvenile antagonism not found in other social mammals. These agonistic interactions may not reflect "dominance" in the traditional sense, and appear to be a form of "tolerated aggression" (Hirsch, 2007).

According to Gompper (2004), males had higher intensities and prevalence of non-replete and replete ticks than did band members during the wet season. Males consorting with bands may gain such benefits such as 
lower ectoparasite loads, protection from potential predators, and protection from other adult males (Gaumer, 1917 apud Gompper, 1995; Gompper and Krinsley, 1992). And factors such as the intensity of intrasexual competition, or food densities, and characteristics such as size, cohesiveness, intra-band relatedness, and the relationship of the male to band members, may all affect the tolerance of adult males by bands, and the decision of males as whether to leave their bands (Gompper and Krinsley, 1992).

In previous studies, it has been suggested that the dichotomous social structure of the coatis may be strongly influenced by intra-specific competition and food patches (Russel, 1982; Russel, 1983; Ratnayeke et al., 1994; Gompper, 1996; Gompper et al., 1997). The dispersal pattern and the home range size involve energetic costs that differs by gender, and affects the foraging success, and as well in the case of males, in the dispute for females during the breeding season (Russel, 1983; Yanoski and Mercolli, 1992; Ratnayeke et al., 1994; Gompper et al., 1997; Valenzuela and Ceballos, 2000). In the case of PEP coati population, some of the adult males are frequently observed foraging with bands instead of remaining solitary. This fact seems to suggest that the foraging competition between genders does not limit coatis' gregarious behaviour, allowing for the constant permanence of the adult male with the band.

Because the PEP is marked by seasonality between wet and dry seasons, coatis behaviour changes accordingly between these seasons. During the dry season, the coati resting period has been recorded mostly taking place around midday and inter-band agonistic interactions increased considerably. Similar findings were reported in Mexico by Valenzuela and Ceballos (2000) and Valenzuela and MacDonald (2002). This seasonal change in daily behaviour pattern of PEP coatis may be explained as an energy-saving strategy, since the winter coincides with the dry season, when food is scarce.

Furthermore, the fact that coati resting period mostly occurred between 11:00 AM and 1:00 PM, may also be associated with low midday air humidity characteristic of the winter in this region. Low air humidity may restrain major physical activities. Similar behaviour has been recorded for coati bands at Fazenda Nhumirim, Pantanal da Nhecolândia (R. A. Mauro, personal communication). According to the meteorological station of the Department of Agricultural Science (UNIDERP), air humidity can reach values as low as $12 \%$, similar to the climatic conditions of a desert.

The above results suggest that seasonality at the PEP causes changes in the availability of resources for coatis, altering their home range areas, their dispersion patterns and their daily behaviour. And our observations regarding male-band associations, agonistic interactions between bands and their daily behaviour emphasize the plasticity of coati social structure, and its potential for future comparative studies.
Acknowledgements - We thank members of the Parque Estadual do Prosa and CAPES for the financial support provided.

\section{References}

ALTMANN, J., 1974. Observational study of behaviour: sampling methods. Behaviour. vol. 49, p. 223-265.

ALVES-COSTA, CP., 1998. Frugivoria e dispersão de sementes por quatis (Procyonidae: Nasua nasua) no Parque das Mangabeiras, Belo Horizonte, MG. Campinas: UNICAMP. [Dissertação de Mestrado].

ALVES-COSTA, CP., FONSECA, GAB. and CHRISTOFARO, C., 2004. Variation in the diet of the brown-nosed coati (Nasua nasua) in southeastern Brazil. Journal of Mammalogy, vol. 85, no. 3 , p. $478-482$.

BARBOSA, AS., 1996. Sistema biogeográfico do cerrado: alguns elementos para sua caracterização. Goiânia: UCG. 43 p.

BEISIEGEL, BM., 2001. Notes on the coati, Nasua nasua (Carnivora: Procyonidae) in an Atlantic Forest area. Revista Brasileira de Biologia = Brazilian Journal of Biology, vol. 61, no. 4, p. 689-692.

BEISIEGEL, BM. and MANTOVANI, W. 2006. Habitat use, home range and foraging preferences of the coati Nasua nasua in a pluvial tropical Atlantic forest area. Journal of Zoology, vol. 269 , p. 77.

BUCKLAND, ST., ANDERSON, DR., BURNHAM, KP. and LAKE, JL., 1993. Distance sampling: Estimating abundance of biological population. London: Chapman and Hall. 432 p.

BURNHAM, KP., ANDERSON, DR. and LAAKE, JL., 1980. Estimation of density from Line transect sampling of biological populations. Wildlife Monographs, vol. 72, p. 1-102.

CHEIDA, CC., OLIVEIRA, EN., FUSCO-COSTA, R., MENDES, FR. and QUADROS, J., 2006. Ordem Carnivora. In REIS, NR., ADRIANO L., PERACCHI, AL., PEDRO, WA. and LIMA, IP. Mamíferos do Brasil. Londrina. 437 p.

CUARÓN, AD., MORALES, MAM., McFADDEN, KW., VALENZUELA, D. and GOMPPER, M. 2004. The status of dwarf carnivores on Cozumel Island, Mexico. Biodiversity and Conservation, vol. 13, p. 317-331.

CULLEN JUNIOR, L. and RUDRAN, R., 2003. Transectos lineares na estimativa de densidade de mamíferos e aves de médio e grande porte. In CULLEN JUNIOR, L., RUDRAN, R. and VALLADARES-PÁDUA, C. (Ed.). Métodos de estudos em biologia da conservação e manejo da vida silvestre. Curitiba: UFPR/FBPN. p. 169-179.

DECKER, DM., 1991. Systematics of the coatis, genus Nasua (Mammalia, Procyonidae). Proceedings of the Biological Society of Washington. Biological Society of Washington, vol. 104, no. 2, p. 370-386.

DIXON, KR. and CHAPMAN, JA., 1980. Harmonic mean measure of animal activity areas. Ecology, vol. 61, p. $1040-1044$.

EMMONS, LH., 1984. Geographic variation in densities and diversities of non-fling Mammals in Amazonia. Biotropica, vol. 16, p. 210-222. 
EMMONS, LH., 1990. Carnivores (Procyonidae). In Neotropical rainforest mammals. Chicago: University of Chicago Press. p. $136-138$

GOMPPER, ME., 1995. Nasua narica. Mammalian Species, vol. 487 , p. 1-10.

1996. Sociality and asociality in white-nosed coatis (Nasua narica):

foraging cost and benefits. Behavioral Ecology, vol. 7, no. 3, p. 254-263.

1997. Population ecology of the white-nosed coati (Nasua narica) on Barro Colorado Island, Panamá. Journal of Zoology, vol. 241, p. 441-455.

GOMPPER, ME. and DECKER, DM., 1998. Nasua nasua. Mammalian Species, vol. 580, p. 1-36.

GOMPPER, ME. and KRINSLEY, JS., 1992. Variation in social behavior of adult male coatis (Nasua narica) in Panama. Biotropica, vol. 24, no. 2a, p. 216-219.

GOMPPER, ME., GINTTLEMAN, JL. and WAYNE, RK., 1997. Genetic relatedness, coalitions and social behaviour of white-nosed coatis, Nasua narica. Animal Behavior, vol. 53, p. 781-797.

GOMPPER, ME., 2004. Correlations of coati (Nasua narica) social structure with parasitism by ticks and chiggers. In SÁNCHEZ-CORDERO, V. and MEDELLÍN, RA. (Ed.). Contribuciones mastozoológicas en homenaje a Bernardo Villa. Mexico: UNAM. p. 527-534.

GOTTESBERGER, G. and GOTTSBERGER, IS., 1983. Dispersal and Distribution in the Cerrado Vegetation of Brazil. Sonderbd Naturwiss ver Hamburg, vol. 7, p. 315-352.

HIRSCH, BT., 2007. Spoiled brats: is extreme juvenile agonism in ring-tailed coatis (Nasua nasua) dominance or tolerated aggression?. Ethology, vol. 113, no. 5, p. 446-456.
MCCLEARN, D., 1992. Locomotion, posture, and feeding behavior of kinkajous, coatis, and raccoons. Journal of Mammalogy, vol. 73, no. 2, p. 245-261.

McFADDEN, KW., 2004. The ecology, evolution and natural history of the endangered carnivores of Cozumel Island, Mexico. Columbia: Columbia University. [Tese de Doutorado].

RATNAYEKE, S., BIXIER, A. and SITTLEMAN, JL., 1994. Home-range movements of solitary, reproductive female coatis, Nasua narica in South-Eastern Arizona. Journal of Zoology, vol. 233 , p. $322-326$

RUSSEL, JK., 1982. Timing of reproduction by coatis (Nasua narica) in relation to fluctuations in food resource. In LEIGHT JUNIOR, EG., RAND, AS. and WINDSOR, DM. The Ecology of a tropical forest: seasonal rhythms and long-term changes. 2 ed. The Smithsonian Institution. p. 413-431.

, 1983. Altruism in coatis bands: nepotism or reciprocity?. In WASSER, SK. (Ed.). Social Behavior of female vertebrates. Academic Press. p. 263-290.

SECRETARIA DO MEIO AMBIENTE - SEMA., 2000. Plano de manejo para a reserva ecológica do Parque dos Poderes. SEMA.

VALENZUELA, D. and CEBALLOS, G., 2000. Habitat selection, home range, and activity of the white-nosed coatis (Nasua narica) in a Mexican tropical dry forest. Journal of Mammalogy, vol. 81, no. 3, p. 810-819.

VALENZUELA, D. and MACDONALD, DW., 2002. Homerange use by white-nosed coatis (Nasua narica): limited water and a test of the resource dispersion hypothesis. Journal of Zoology, vol. 258, p. 247-256.

YANOSKI, AA. and MERCOLLI, C., 1992. Preferencias de hábitat y actividad del coati común (Nasua nasua) en la Reserva Ecológica el Bagual (Argentina). Miscelláni Zoológica. vol. 16, p. $179-182$. 